\title{
Gabriel Weston: A window on to a hopeful landscape
}

\author{
Gabriel Weston ENT surgeon
}

Surrey

Window bars are set to be phased out in all UK prisons and replaced with toughened glass. This is a safer alternative in terms of preventing contraband, and giving prisoners a more homely environment has been shown to improve their prospects of rehabilitation.

There will always be those who believe that prison ought to be horrible, that the people who end up there deserve what they get. But the truth is that our detention centres are crammed with many people we should consider patients.

An article published in Lancet Psychiatry in 2018 estimates that $90 \%$ of our incarcerated population have at least one mental or substance use disorder. ${ }^{1}$ A recent survey from the National Audit Office showed a $73 \%$ increase in acts of self harm in prison from 2011 to $2016 .{ }^{2}$ Medical Justice, a charity that campaigns for detainees' health rights, says that many of the 30000 people detained every year in UK immigration removal centres have substantial unmet health needs, as well as often having experienced torture and trauma.

Giving prisoners a more homely environment has been shown to improve their prospects of rehabilitation

Living with Buildings, a beautifully curated exhibition at the Wellcome Collection in London, interrogates how our built environment contributes to our physical and mental health across a range of settings.

Standing in front of Andreas Gursky's massive 1993 photograph of the Mouchotte building in Paris with its rows upon rows of identical windows, ${ }^{3}$ you sense the desolation that the inhabitants might feel in this building on the biggest housing estate in Montparnasse. By contrast, poring over Alvar Aalto's designs for his 1930s tuberculosis sanatorium in Paimio, Finland-with its jewel coloured interiors, ergonomic furniture, and light falling through every window—can really lift the spirits.
Near the end of the exhibition a video showcases patients with cancer enthusing about their local Maggie's Centre. Thanks to their eponymous founder, more than 25 of these buildings have emerged around the UK in the past two decades, providing all manner of support to people with a cancer diagnosis. Designed by some of our most visionary architects, each centre is original while honouring a shared brief: to be light, inspire imagination and, above all, make a person feel valued.

I've been inside several detention settings in the past year, including prisons, a secure psychiatric unit, and an immigration removal centre. One of these places was well appointed enough, but I found it most terrifying, even as a visitor.

Maggie's designers seem to understand intuitively that, when the architecture of our most intimate home-our own body-is disrupted by disease or catastrophe, what we need above all else is harbour, a view on to a hopeful landscape.

Perhaps one day we'll extend this consideration to the least regarded ill and vulnerable members of our community. If we're really interested in providing a road back for these people, we need to start thinking much more creatively about the places they're forced to call home.

Competing interests: I have read and understood BMJ policy on declaration of interests and declare that I have no competing interests.

Provenance and peer review: Commissioned; not externally peer reviewed.

1 Jack HE, Fricchione G, Chibanda D, Thornicroft G, Machando D, Kidia K. Mental health of incarcerated people: a global call to action. Lancet Psychiatry 2018;5:391-2. https:// www.thelancet.com/journals/lanpsy/article/PIIS2215-0366(18)30127-5/fulltext. 10.1016/S2215-0366(18)30127-5 29699739

2 National Audit Office. Mental health in prisons. 29 Jun 2017. https://www.nao.org.uk/ report/mental-health-in-prisons/.

3 Dobson J. Living with Buildings: new Wellcome show looks at urban architecture and health. BMJ 2018;363:k4235. 10.1136/bmj.k4235 30305271

Published by the BMJ Publishing Group Limited. For permission to use (where not already granted under a licence) please go to http://group.bmj.com/group/rights-licensing/ permissions 